\title{
An E-model of a Flipped \& Heuristic and Functionally \& Logical Learning for the Generation " $Z$ "' in the Classwork
}

\author{
Slavoljub Hilčenko \\ Vocational College for Education of Preschool Teachers and Sport Trainers in Subotica, University of Novi Sad, Republic of Serbia
}

Email address:

slavoljubhilcenko@gmail.com

To cite this article:

Slavoljub Hilčenko. An E-model of a Flipped \& Heuristic and Functionally \& Logical Learning for the Generation "Z" in the Classwork. International Journal of Elementary Education. Vol. 4, No. 3, 2015, pp. 65-79. doi: 10.11648/j.ijeedu.20150403.14

\begin{abstract}
Which system of elementary school-education should be preferred, whether the functional and logical one (more humane?) or the reproductive one (drill system?) Is it the right way to choose both of these as Tolstoy's method since it may be smarter option? The elementary school educational system in Serbia is prevalently based upon the reproductive. Is it the reason it faced its dead-end? The objective of this paper is to promote an e-model of a flipped \& heuristic and functionally \& logical learning with the example of animated content. An animated movie does not require any additional motivation to watch and therefore it is quite receptive as a learning source for the Generation "Z" attending school classes in the elementary schools. The presented example of the animated scientific task intends to stimulate functional and logical thinking at pupils and the model is applicable for each and every school subject existing in the syllabus. The results of the conducted research at the sample of the pupils attending fourth grade were expected and support the claim of pupils being unprepared for this method of learning in great percentage due to the reason of the implemented system even though the motivation during the procedure was at very high level. Is it possible that the very reason for the poor results at PISA test can be traced all up to this initial flaw of the educational system incapable of fulfilling the need for early stimulation of the development of the synapses that are directly responsible for the intellectual capabilities of children and therefore for the level of the Gross domestic product of a country?
\end{abstract}

Keywords: Flipped-Heuristic E-Model of Learning, Functionally-Logical Thinking, Animated Movie, Generation “Z”, Manipulative-Experimental Work, Wide Range of Possible Application

\section{Introduction: Pro et Contra}

Lev Nikolayevich Tolstoy used to say that the,"main characteristic of each and every art form is contained in the sense for the balance"... we add to this that it stays true not only for arts but education, as well.

The best educational system in the world is South Korean and it is followed by another three countries of South-East Asia, Japan, Singapore and Hong Kong, whilst Finland which educational system was the leading one in the Europe and the world takes the fifth place according to the recent published rating comprising 40 countries that have best results in the research.

Economist Intelligence unit (EIU) have done analysis for the company Pearson, that undertakes researches and inquiries on educational systems and published the list of 40 countries that have the most efficient school system in the world for the year 2014 .

Rating (Index of cognitive skills and educational attainment) is assembled based upon the sequence of international tests and indices at the domain of education that costs countries taken on the whole more than 5 trillion dollars.

The ration of the first 20 for the year 2014 goes as following:

- $1^{\text {st }}$ South Korea (which took second place in the previous rating in 2013),

- $2^{\text {nd }}$ Japan (improved its rating for two positions),

- $3^{\text {rd }}$ Singapore,

- $4^{\text {th }}$ Hong Kong,

- $5^{\text {th }}$ Finland (Finland was the first in 2012),

- $6^{\text {th }}$ the Great Britain,

- Canada, Netherlands, Ireland, Poland, Denmark, Germany, Russia, USA, Australia, New Zealand, Israel (which was never before amongst the first 20), Belgium, Czech Republic (which was never before amongst the 
first 20, as well).

The list of the 20 best educational systems ends with Switzerland.

The cause of the South Korean and Finland successful system are the great teachers. These countries rely on talented teachers, not talented pupils, especially in Finland where the competition to take the jobs of teaching is fierce and where Teacher faculties accept 1 of 12 of the applicants trying to become students. After graduation each and every teacher in Finland in order to get the job in schools must acquire the master degree so as to have the mere chance to teach in elementary schools.

Here it is the order of the most successful school systems taking places 21 to 40 in the aforementioned rating: Norway, Hungary, France, Sweden, Italy, Austria, Slovakia, Portugal, Spain, Bulgaria, Romania, Chile, Greece, Turkey, Thailand, Columbia, Argentina, Brazil, Mexico and Indonesia.

The Pearson Company assessed cognitive abilities starting from the results of the international research PISA upon which values the level of literacy was compared and knowledge in mathematics and other sciences were compared, as well. For the measuring of the educational rating the level of literacy and general preparedness were taken into consideration and evaluation.

This concept of rating provides information on how much money is spent for the improvements in education in various countries, how much money teachers receive as their salaries, what is the general level of preparedness amongst pupils, what is the rate of the unemployed and contains data on life expectancy in the studied countries.

According to the data received via the research conducted by Pearson Company done in 2012 and 2014, presented by EIU, Finland and South Korea are the absolute leaders of the educational rating system known Learning Curve, considering the general index and level of education, as well. The educational systems of these distant countries settled on two different continents vary quite significantly. Thus, in South Korea, similarly to other Asian countries, the emphasis is on learning by heart and maximal period of time spent at classwork. After school classes most of the pupils attend private lessons or spend their time off the school in repeating what was learnt under the professional conduct of a private teacher. As they approach the end of schooling the number of additional classes rises. Schools in Finland represent the very opposite to the schools of South Korea regarding time spent at school classes and time spent in listening lectures. The main principle of school work in Finland is to help pupils understand the learning subject to apply the knowledge and to merely reproduce it. The same model is present in other Scandinavian countries.

The paramount thing is the culture the society and the state support the value of education. Speaking of truth, other countries also support education but education in Finland and South Korea and the support they provide present concrete reflection of the very ethical and general objectives of their societies as a whole. (BrankoRakočević 2014) South Korea have taken the leading position from Finland. (Chronicle,
The Educational Review, No. 2623 (22), year LXX)

Unfortunately the republic of Serbia in the year of 2014 has not reached enough money in order to implement PISA testing for its pupils. Is it the only reason or may it be that badly ranked pupils in the previous period have been taken as a kind of justification so as to forget about this problem for a while. This can prove very bad for our educational system very soon.

At the most recent international pupil's testing (Program for International Student Assessment), the pupils form Serbia took the last position in ranking amongst European countries in the sequence of test that measured mathematical knowledge, natural sciences knowledge and in proofreading of the texts. It is obvious that the knowledge pupils acquire in our schools does not even satisfy the average criteria of this international testing system.

PISA tests represent the largest and the most significant international inquiry considering achievements of pupils in domains of reading, mathematics and scientific literacy, and educational experts explain that PISA test does not search for the level of the acquired and the adopted of the school program and plan. PISA test search for the indices that show how well pupils manage the knowledge and how much the knowledge in each domain help them in daily ordinary life routines and situations and whether the pupils have or have not understood and acquired so called scientific literacy.

"The scientific literacy in PISA testing project is defined as the capability to use what was learnt, to identify scientifically relevant issues and make conclusions based upon scientific results in order to understand better the world around us".

Each and every research conducted in Serbia on the effects of elementary school process proves that our children have encyclopedia knowledge that is non-functional and from year to year we tend to get even worse. Namely, the first research on the effects of elementary education conducted by the Institute for psychology in 1989 and that was repeated in 2003 for the need of UNICEF study shown that our educational system was and still is inefficient and that our pupils have non-functional and reproductive knowledge. The pupils take this kind of knowledge in high schools where we may see the consequence in production of professionally incompetent individuals. This is how the experts assessed the results of the aforementioned research.

In the period from 1989 to 2003 the war and the destruction of the former state of Yugoslavia took place but the educational system did not collapse but remained consistently bad. This is a conclusion of the experts who use the syntagmatic phrase of "non-efficient system sustainability". From their point of view PISA results do not represent "an educational incident" but chronic state that lasts more than 20 years (http://www.politika.rs/rubrike/Drustvo/t49789.1t.html).

\subsection{School $=$ Untill Now=Boredome}

"School from its beginning to these days have not succeded in fullfiling its basic purpose-to serve life!" (Bill Gates) 


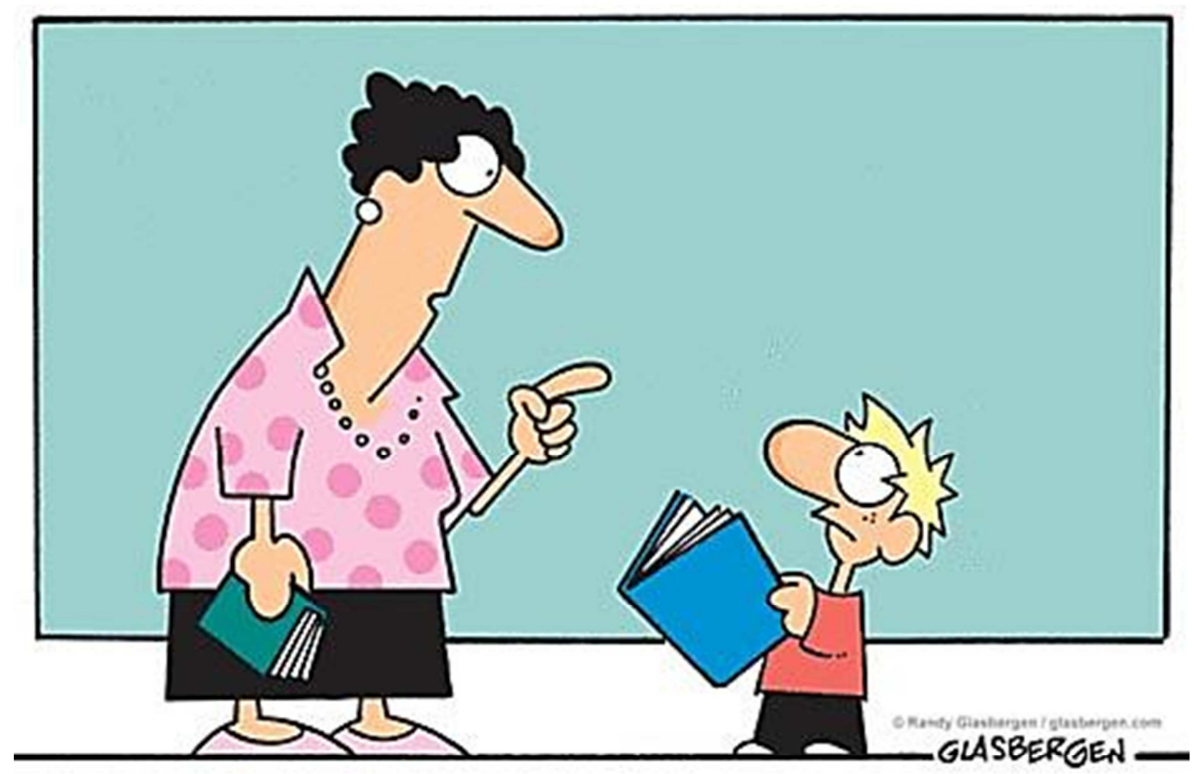

\section{"It's called 'reading'. It's how people install new software into their brains"}

Caricature 1. Generation "Z" and traditional School.

According to Slavoljub Hilčenko (2014a, 241-244) the pupils in elementary schools in Serbia yearn for changes and educational models that are present and actual are obsolete and frustrating. New and contemporary approaches to teaching seem to be deliberately absent in Serbian schools. In nowadays school pupils are bored there is no challenge in it! And whilst the ideas of our innovators, for example Mensa methods on functional learning implement and apply in 14 European countries ourschooIs seem to remain closed in Circulus

vitiosus(https://www.youtube.com/watch?v=Q6GKR2MYZR 4).In this sensethe permanent and life long leraning of the teachers must go "hand in hand with the times we live in and not to be reduced to the enthusiasm of a couple of individuals!"

According to Jean Piaget and Barbel Inhelder (1978) only when a child is 10 years old it is ready to manipulate complex abstract thinking. However, this theory was written 50 years ago and according to Ranko Rajović this theory does not have a steady grounds nowadays. (2009) A child today and 50 years ago is not the same child. A lecturer $\mathrm{PhD}$ Ranko Rajović, the author of Nikola Tesla Centre (NTC) system of learning, doctor of neurophysiology, the president of Mensa World Committee for gifted children and UNICEF collaborator on the project of early intellectual development stimulation of children stresses that the "NTC-learning system", is the program which is based upon scientific research at the domain of neurophysiology and which allows children up to the age of seven to develop even $75 \%$ of neuron links, so called synapses directly responsible for the intellectual capabilities of children.

The fact is that intelligence does not merely depends on the number of neurons anent it is not conditioned only by genetic potential but also by the number of links amongst neurons/synapses. The period until the age of seven is the most precious for the formation of new neuron synapses that is neuron links. NTC-learning system tackles the issue of how to stimulate development of synapses that is how to stimulate development of immense infant potential before school and during the school-time. This question is directly related to the Gross domestic product of a country.

NTC-learning system is directed to the development of cognitive abilities of children and it is based upon the researches undertaken by Organization for Economic Cooperation and Development (OECD 2010) which warns that a brain constitutes $75 \%$ of all neuron links in the period before the age of seven (the biggest potential for the development of synapses is between ages of 2 and 4) and that $50 \%$ of these synapses are established before the age of 5 . This argument seems to be enough assuring that we should point our attention towards preschool period, the efficiency of learning and usage of children memory. If we manage with only $25 \%$ of capabilities that are remaining regarding the usage of brain capacity potential in elementary school period and high school period then it is of outmost importance knowing how children are developing up to the age of seven.

NTC-learning system includes learning based upon theoretical grounds of neuroscience neuropsychiatry and other sciences especially pedagogic such as family pedagogy, didactics and methodic for preschool and elementary school level. This learning system represents operationalization of theoretical knowledge of the aforementioned scientific branches that makes valid index and example of how to relate theory and practice. Thereby it represents a new approach It 
is fairly well structured, applicable within family, kindergartens and school classes in the elementary schools."

On the other hand, e-learning (educational video games and animated movies) have proven their educational, functional and motivational preponderance in comparison to the traditional learning forms. There are numerous examples for this

claim

(http://www.ixl.com;http://www.brainpop.com/;http://

www.lilibi.si/).

E-learning becomes increasingly attractive learning source thanks to the quality and professional and scientific approach to development. This learning becomes favorite choice of acquiring knowledge in elementary schools. Here we think about knowledge from the domain of cognitive thinking the principles of multimedia shaping of leaning units (Richard E. Mayer 2005), learning theories, principles in creating animated applications, imagination, creativity and talent of web, graphical and instructional designers, as well. (Slavoljub Hilčenko 2012a, 2012b)(http://hrcak.srce.hr/index.php?show=clanak\&idarticl ejezik= 118199),(http://teme.junis.ni.ac.rs/teme12012/teme\%201-2012-18.pdf).

"Teaching content dressed into the attractive form of animated movie have proven their superiority in comparison to the classical methods because these new forms do not require any additional motivation. On a very popular website BrainPOP(http://www.brainpop.com/), the results of an experimental research are presented alongside with the effects of the application of animated content in teaching process all took together in comparison to classical approaches that did not include such contents"(Slavoljub Hilčenko 2011).

John B. Black: "We are aware of the fact that most of children fancy video games and some researchers think they are powerful learning tools"(http://edupoint.carnet.hr/casopis/57/clanci/1.html).

\subsection{Three Learning Methods for New Generations}

Finally, the Generation "Z" comes to its own! Namely, this generation, born between 1990 and 2000, and later have been growing up in digital era alongside with informational technologies. Studies confirm that their senses are adapted to contents that are emitted via contemporary media. This is not about genetics but about the specific reaction of organism and brain produce in such an environment (caricature 1). The questionnaire that parents of these children got to fill in represents their positive and affirmative attitude towards application of modern technologies within the process of institutional education of their children. Of course, here we do not talk about kindergartens and schools. However, some of our unacquainted teachers nevertheless say: "kids nowadays are bored anyway, that kids cannot express themselves, that they are illiterate and that they read very little..."

Contemporary schools ought to offer environment compatible to the Generation "Z" and furthermore appropriate teaching contents, models and learning methods in the form of splendid graphical applications. Owing to pronounced perceptive abilities of the youth today they accept very easily these visual forms and learn more effectively. Teachers must follow these trends and offer contents that are rather watched and perceived that taught or listened. The model that satisfies the needs of the Generation " $Z$ " is the method of flipped learning (Slavoljub Hilčenko 2014b, 26-30).

Sociologists for years warn us about the fact that traditional teaching/learning methods are not compatible to new generations, born in the digital era. Blackboard and chalk are completely obsolete means in teaching process when the reality of the Generation " $Z$ " is made of computers, tablets; they interact on virtual social networks and use on a daily basis the Internet. Before anything else the approach to the lessons should be changed. Then teaching means and methods should be altered and improved and the level of interactivity must be raised. If done the opposite way we risk losing the focus and attention of generation to come as we are losing them as they are right now.

a) The attention has to directed at visual learning methods

Studies have shown that the young today differ a lot in comparison to older generations. The environment of this generation are graphically rich web technologies, HD screens of high resolutions and large dimensions and overall the satiety with information, as well. The result of these is pronounced perceptive abilities of the young that accept easily visual forms and learn more effectively. The teachers have to go hand in hand with the times and adapt their lectures and class works to the needs of the new generations.

b) Focusing on critical thinking and problem solving not on memorizing information

There will always be the ones who will easily acquire some information simply by memorizing. Whether these ones will be capable of using this knowledge in real life conditions and at tasks is the problem. Some consider that today it is especially not necessary to remember some information when they can be reached by the mere click of the mouse at the Internet. It is clear enough that strategically important education must tackle education of the young regarding development of critical thinking and regarding learning the application of knowledge in problem solving and not involve itself in creating experts who will always and in any time be able to tell the exact dates of some historical events, values of mathematical constants or some scientific theorems. The entrepreneurship is considered the basis of future economic development and therefore it is important to train the young and provide them the knowledge that will aid them in the struggle to thrive at the market.

c) Adapt lectures to the needs of the young

The big flaw of the Generation " $Z$ " is the lack of attention after a while as the result of too much information received. Simply, information saturation and accelerated cognitive activities add to the fact that only after couple of minutes their brain cannot receive new information and it requires rest time. Enough sure, the 45 minute class is impractical when we talk about the attention of the twenty year old 
students. Lessons should be divided into smaller segments and it is necessary to enable the young the approach to the knowledge when they are ready to acquire. Here we come across distance learning methods, e-learning platforms and systems that can easily be reached via the Internet and that are available at any times(http://www.valentinkuleto.com/2012/05/3-metodeucenja-za-nove-generacije).

About the significance of the informational technologies for the young today in their process of learning contributes the following (Grunwald Associates LLC. 2013), (http://www.corp.att.com/edu/docs/mobile_kids.pdf).

\subsection{Flipped Learning}

One of the increasingly more and more attractive teaching/learning method is the flipped classroom model. Flipped classroom model functions in such a manner that teachers prepare video lessons for pupils or prepare some type of interactive on-line contents that pupils can repeat at home and then practically apply the acquired knowledge. Therefore, the principle of this learning is to teach oneself lessons and then approach the exercises and group work with other children. Also, the Internet has become a ubiquitous and unavoidable knowledge treasury one can reach from any place on the planet. This is exactly what some sites have been striving to in order to make education available to everyone wherever they may be.

In kindergartens around the world iPod telephones, interactive blackboards and tablets have been in use for some time. This way using these technologies children learn in an interactive way and it appears as fun to them. Learning mathematics has never been more interesting than it is now. On iPod telephone or a tablet or on e-blackboard children using touch screen may add or do subtraction by direct manipulation of the application so as to learn whilst they play. All of it is accompanied by great graphical features so as to draw attention of the children and keep the focus (http://www.sk.rs/2013/02/skin03.html).

According to John B. Black "the efficiency of learning by direct manipulation of animation process reveals itself at the example of functional relations. Pupils that have learnt this way received better results comparing to the pupils that learn by reading the text with occasional photograph or illustration or even the ones who learnt by watching a movie. Namely, the results are prevalently these due to the fact that the pupils were engaged via their activities they took when they manipulated parts of the animation and when the learn relations existing within the animation, so it was not the superiority of the technology that contributed to these results but the activities"(http://edupoint.carnet.hr/casopis/57/clanci/1.html).

Our class is prepared so as to using a Flipped classroom model pupils have a task to find at least one way how to check whether an egg is fresh using the Internet and to demonstrate their findings, in group of 5 to 6 pupils, in presentation before their classmates. At the first class the groups provide presentations and demonstrate them experimentally.

A day earlier the teacher provides an example: "Eggs are set in a deep dish filled with cold water. Completely fresh eggs will sink at the bottom and the old ones will float. You may check whether an egg is fresh by putting an egg into a dish. If it sinks, it is all right, if it does not sink the egg is bad. This happens because through the egg shell an egg takes in the air. In time membrane inside the egg shell gets shrunk the air pockets between the egg and egg shell get filled by the air resulting in floating egg. Older eggs have thin whites and less round yolks that are easily shred when en egg is being cracked."

Here are some possible pupil's examples:

1. Group: Whether an egg is fresh you can check always... by following this procedure: poor some water in a dish and add some salt. If the egg goes horizontally at the bottom than it is very fresh and if the sharper pole of the egg is directed towards the surface it is not fresh. If the egg floats it is bad (http://www.smedia.rs/ona/vest/8142/a.html?id=8142).

2. Group: Eggs become bad earlier by the effects of light, heat and oxygen from the air (http://www.ishrana.net/MESO-RIBA-JAJA-Jaja-324).

3. You can discern fresh eggs from the boiled ones when you spin them on a flat surface. The boiled eggs spin regularly and the fresh eggs do not (http://www.zalogaj.com/pages/view-224-korisni-saveti -drugi-deo).

4. Group: The freshness of eggs can be easily checked by directing strong beam of light that can detect any abnormality, broken egg or other defects. A fresh and qualitative egg has thick white on the top and oval yolk and hard, smooth preserved egg shell. It must not churn inside when shaken if it is fresh (http://www.yumama.com/dete/ishrana-dece/1565-jajeje-zdrav-izbor.html).

5. Group: When en egg is broken and spread on a pan the yolk is separate from the white and convex. A fresh egg has pleasant

smell(http://www.yumama.com/dete/ishrana-dece/1565jaje-je-zdrav-izbor.html).

Thus, all groups are presented with the rest ways of checking eggs. The teacher contributes by adding something to the lectures and demonstrations and correct eventual errors.

The teacher provides a shorter scientific explanation: In order to secure initially good quality of eggs in the hot seasons it is necessary to gather eggs more frequently, to cool tem down promptly and to preserve them in cool $\left(10^{\circ} \mathrm{C}\right)$ and damp $(85 \%$ of relative humidity) chamber (http://poljoprivreda.info/?oid=6\&id=234).

Before anything, you tend to buy and use fresh eggs. Every egg is permeable because it is necessary for the egg to breathe inside. In the bottom part of an egg there is so called air pocket. If it is stored inappropriate or for too long this pocket gets fuller and fuller with air and by this we can approximately determine the egg freshens. There is a certain 
rule that an egg can be eaten in 21 days from the day it got out of a hen. The simple test to check how old an egg is can be done by submersing the egg in a glass filled with water. If it sinks completely and set itself horizontally it is very fresh, only few days old. If it leans somewhat it is as old a week and if it stands vertically on its sharper pole, then it is old, and perhaps bad. The test works only if there are no fractures on the egg shell that may allow receiving more air inside (http://www.domaci.de/viewtopic.php?t=939).

\subsection{Heuristic-Programmed and Functional-Logical E- Model of an Animated Scientific Task}

At the second class the teacher says to the pupils that they will watch a presentation of an unusual way to check whether an egg is bad or fresh. Regarding this, the teacher plays the application and disguised pupils dressed as Galileo Galilei says the following information to the pupils (picture 1):

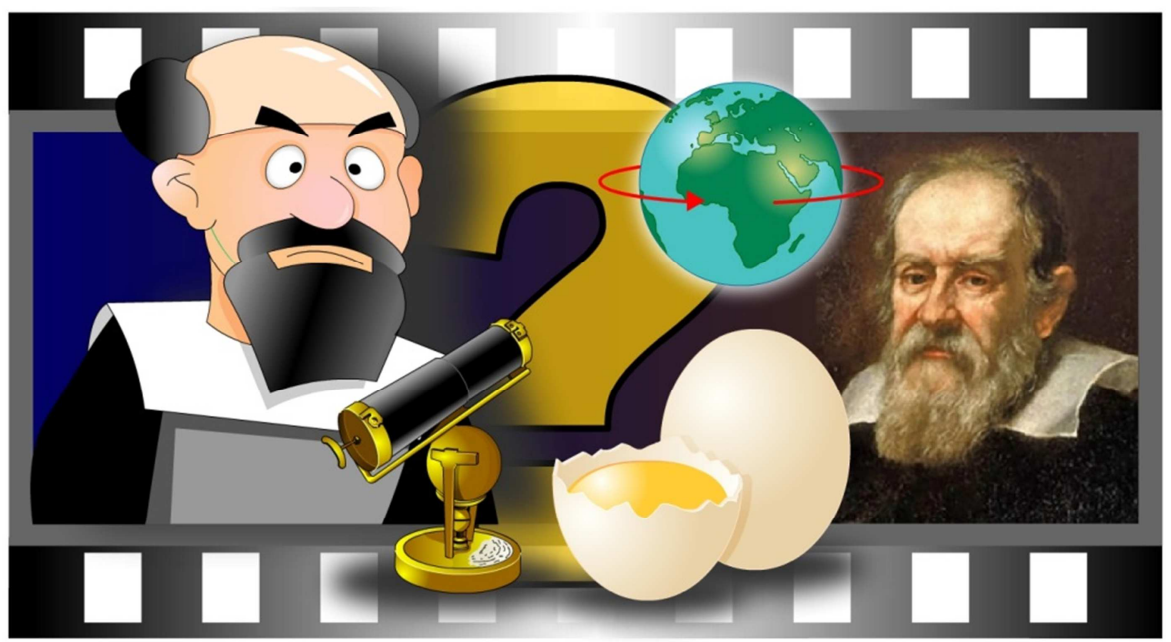

Picture 1. the beginning of the animated heuristic-branched scientific task.

"Galileo Galilei (1564-1642) was an Italian astronomer, physicist, mathematician and philosopher whose researched were the foundations of modern physics. He was the forst one to construct a telescope which enabled people to see the satellites of the Jupiter. Galileo was the first man who doubted the findings of Aristotle, after several centuries and proved that regarding some issues Aristotle was wrong and provided evidence for the claims. Thus, Galileo was the first individual of the New Era that used experimental methods. In order to save himself from the execution that was coming as the real threat of the Inquisition he had to deny all the claims he did including the one about the Earth moving around the Sun and around its axis. The legend says that just before he died he said his famous sentence - "Albeit It does move!"

Our application that we shaped as heuristic-programmed approach to learning presents a model of animated movie. The application of the animated e-task was made on the platform Adobe CS5, and sound records were processed using Sound Forge Pro 11. The size of our touch screen application is $11,2 \mathrm{MB}$.

Programmed learning consists of interconnected parts that are divided which a pupil passes through successively, step by step. After each step was done a pupil revises the knowledge and advances individually according to the knowledge the pupils acquired in the previous period. It can be successfully programmed tightly connected and structured parts of the class work units that present basic knowledge pupils should adopt. A programmed learning can be linear and branched.

On the other hand, heuristic as a science tackles the methods and principles of problem solving, learning and discovering new ways and it is based on learning sourcing from the experience. Heuristic methods are used to accelerate the process of finding a good solution in situations when undertaking a full scale investigation or research is not practical. The examples of this comprise using different general rules, guessing, intuition, common sense, logic and functional thinking (http://sr.wikipedia.org/wiki).

The teacher proceeded with the aforementioned example and presents experimental and functional-logical task under the name of: "Albeit It does move!", which determines whether eggs are fresh. The task is purposed for the optional elementary school subject Having Our Hands in Tests(http://rukautestu.vin.bg.ac.rs/?Page_Id=50).

The model of this heuristic-programmed task is solved in a couple of steps which tacitly and explicitly contain educational components.(http://www.iosrjournals.org/iosrjrme/papers/Vol-1\%20Issue-3/G0134449.pdf),

(http://hrcak.srce.hr/index.php?show=clanak\&id_clanak_jezi k=188976),(https://www.academia.edu/4393470/A),

(Slavoljub Hilčenko 2013a, 144-151, 2013b, 774-781).

The neccessary means for the group work:

1. One tablet per a group,

2. a questionnaire sheet (for the whole group or for each pupils) and

3. three colored eggs, from which only one is fresh (pupils get eggs in the four step).

The taxt of the task is:

Whether the eggs are fresh? There is an unusual way to determine this! 
You must not break the eggs during the task sovling!

Think through very carefully about provided answers and write down your explanation on the questionnaire sheet!

STEP 1. Think well! Choose the number of eggs you think are required in order to do the experiment which determines whether the eggs are fresh or bad (explain the choice you made!):

a) three eggs,

b) one egg and wooden red whip topor,

c) two eggs and a hammer.

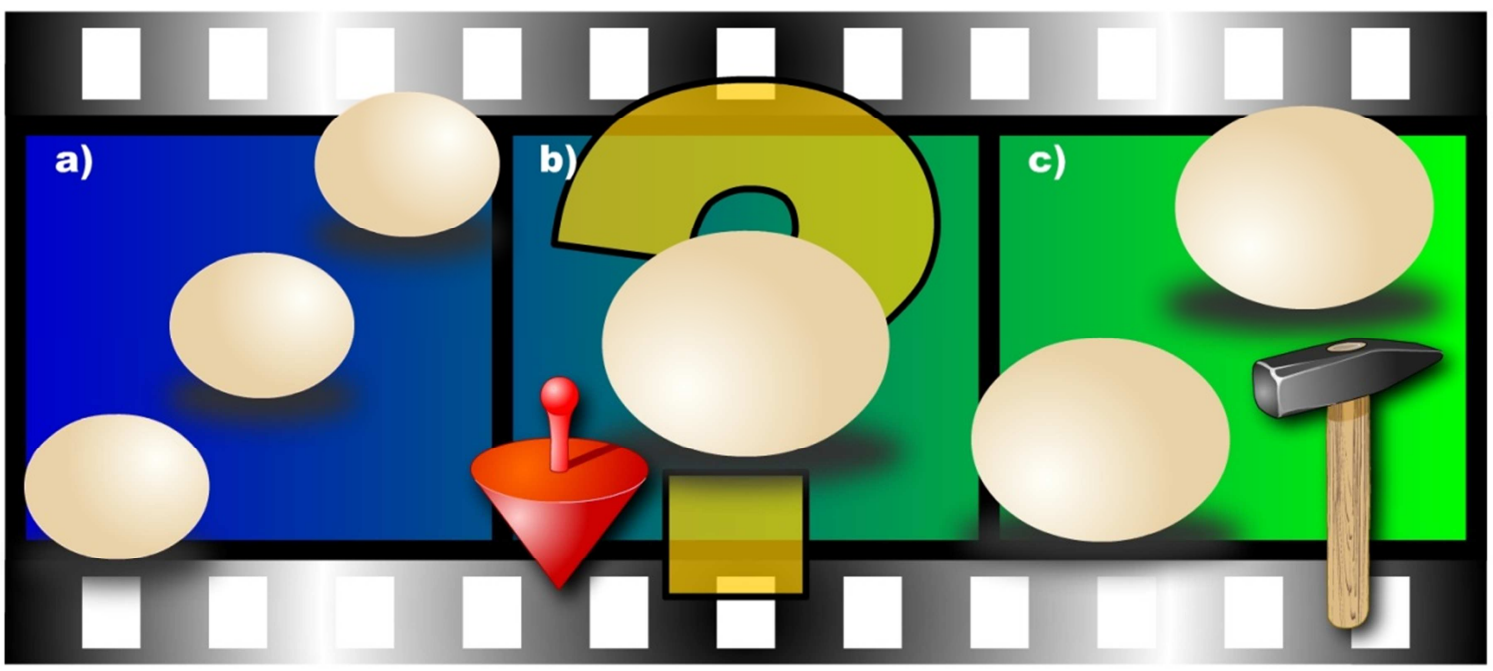

Picture 2. STEP 1.

In the algorithm application, correct answer is bolded for the reader. When the wrong answer is selected pupils get to watch a part of animated movie thta leads to dead end and then direct them to the previous step!

STEP 2. Think well! Whether you will choose the following eggs:

a) eggs colored in three different colors (green, red and yellow),

b) eggs and a tea spoon,

c) eggs and a darning needle.

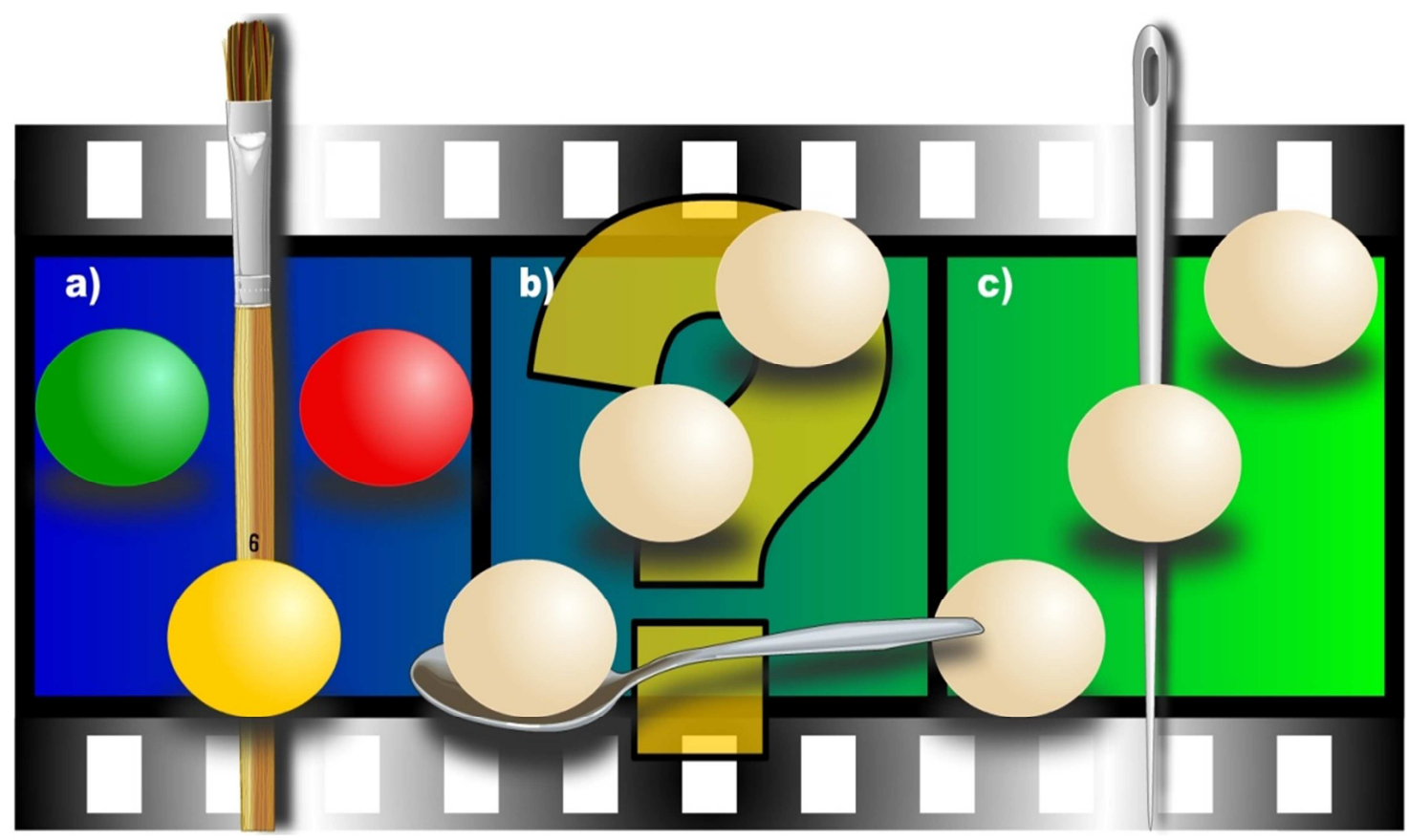

(explain your choice!)

Picture 3. STEP 2.

STEP 3. How many hands do you need do do the experiment?
a) three hands,
b) two hands or
c) one hand. 


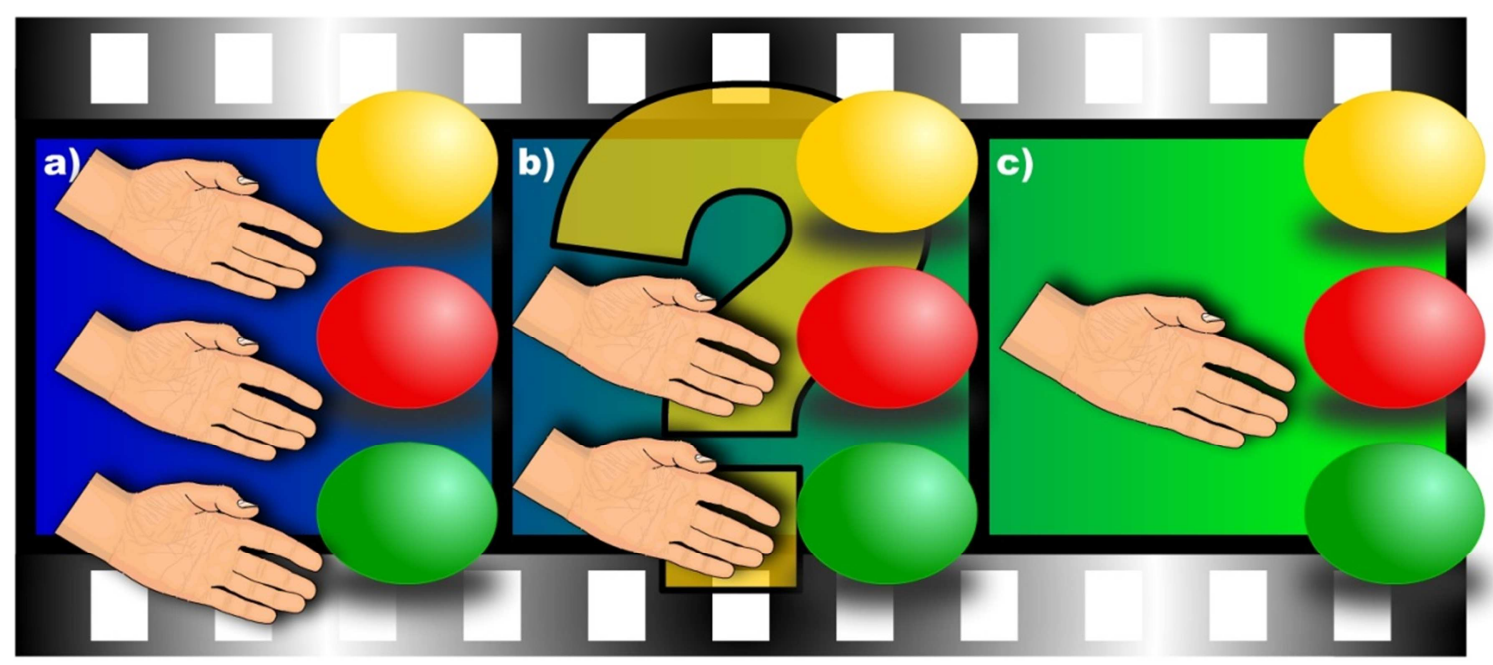

(explain your choice!)

Picture 4. STEP 3.

STEP 4.Think well now! Choose the right order of the eggs that will lead you a step further to the solution. After choosing the right answer you have to approach to the practical solving the experiment according to the instructions on the pictures a, b i c (the experiment firstly does the most skillful pupil in the class): a) the yellow egg is in the middle, red one up, green one down. What do you notice?

b) the red egg is in the middle, green one up, yellow down. What do you notice? or

c) the green egg in the middle, red on up, yellow one down. What do you notice?

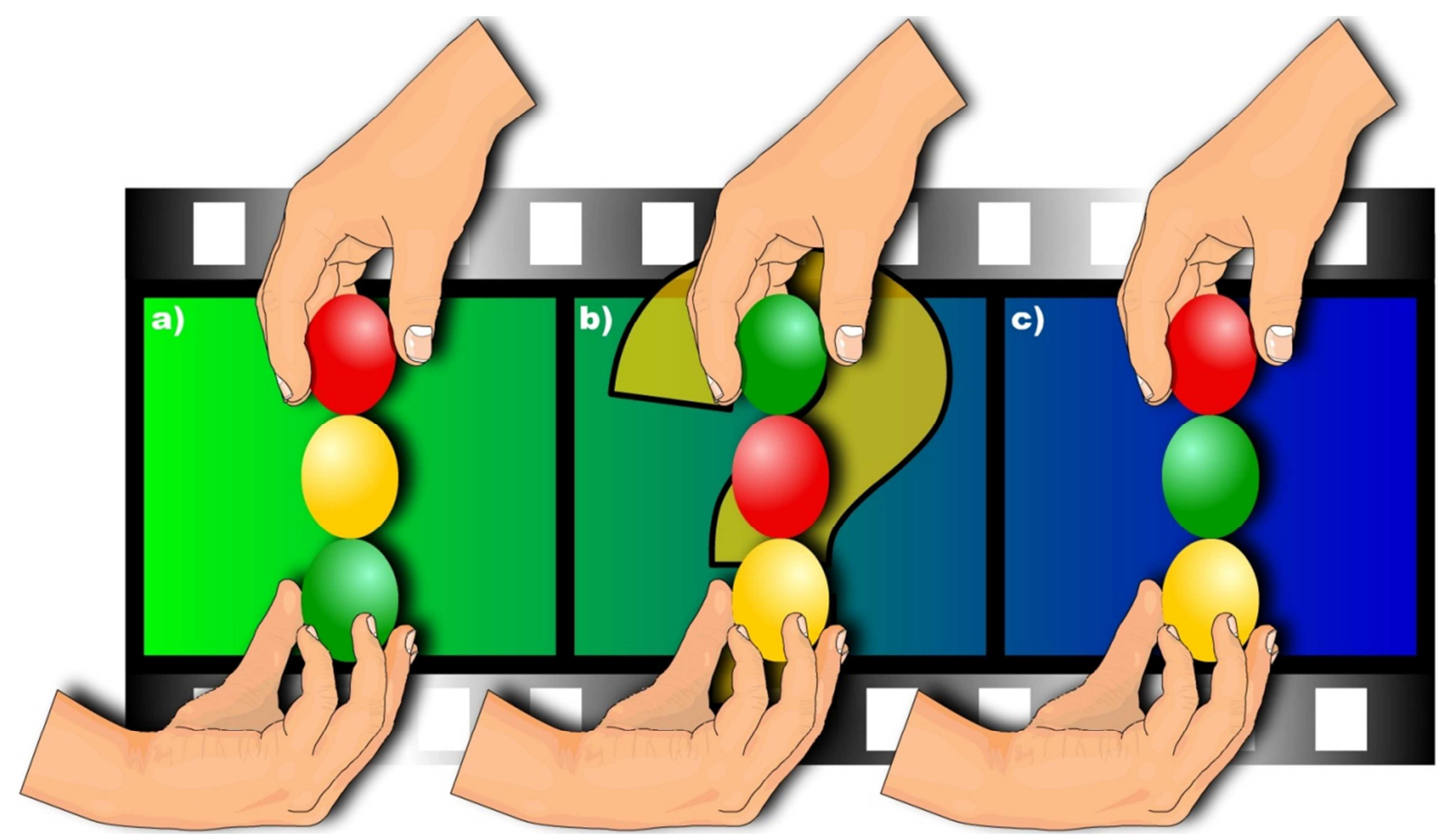




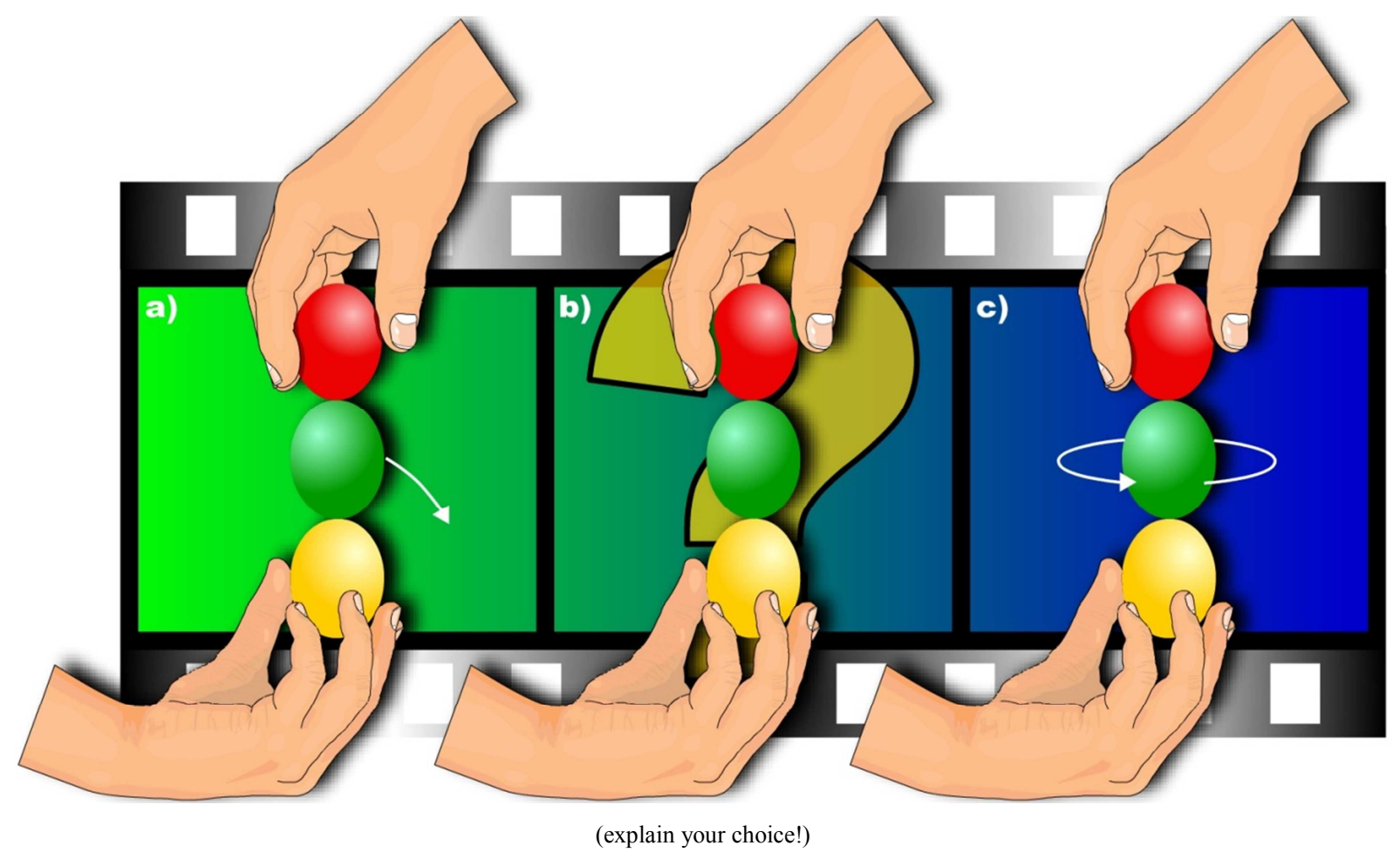

Picture 5. STEP 4.

STEP 5. Attetion! Carefully choose the right anwser that will lead you to the solution of the experiment:

a) The egg that is fresh, revolves around its axis thank to the Sun. Everything that moves around is propelled by the Sun. Wind that is blowing, a stream murmuring, any movement in nature is propelled by the energy coming from the Sun.

b) The egg that is fresh revolves around its vertical axis whilst its poles are held by the rest two eggs. Namely, the content of the egg in the egg shell is evenly disposed and due to the gravity of the Earth it revolves around its axis.

c) The egg that is fresh revolves due to the centrifugal force that is produced by the stream of air from the door towards the windows in the classroom.

In the case of correct answer the pupils get to watch the whole animated movie, picture 6 .

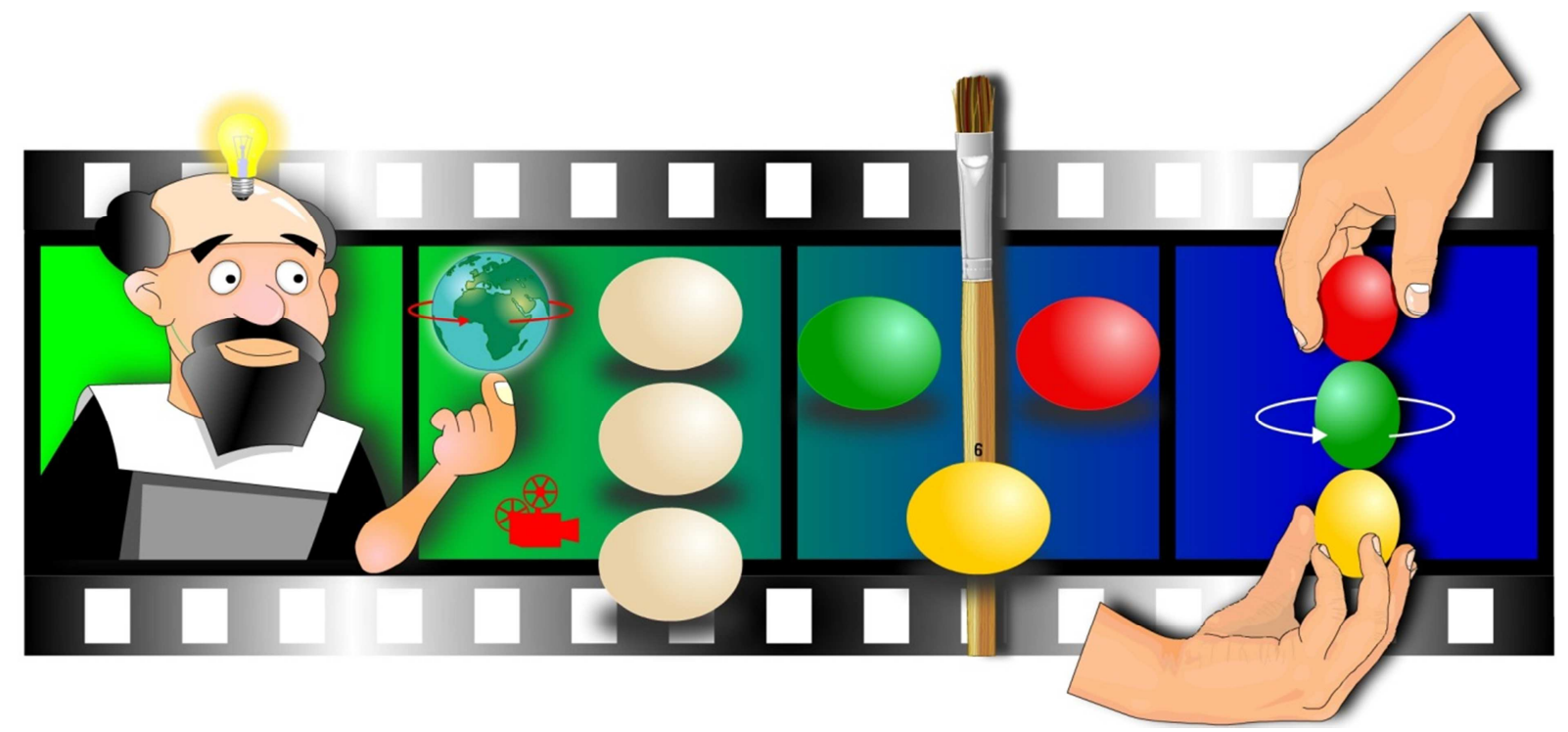

Picture 6.animated movie: the presentation of the solution for the scientific task.

The algorithm scheme of solving the heuristic-branched scientific task, chart 1: 


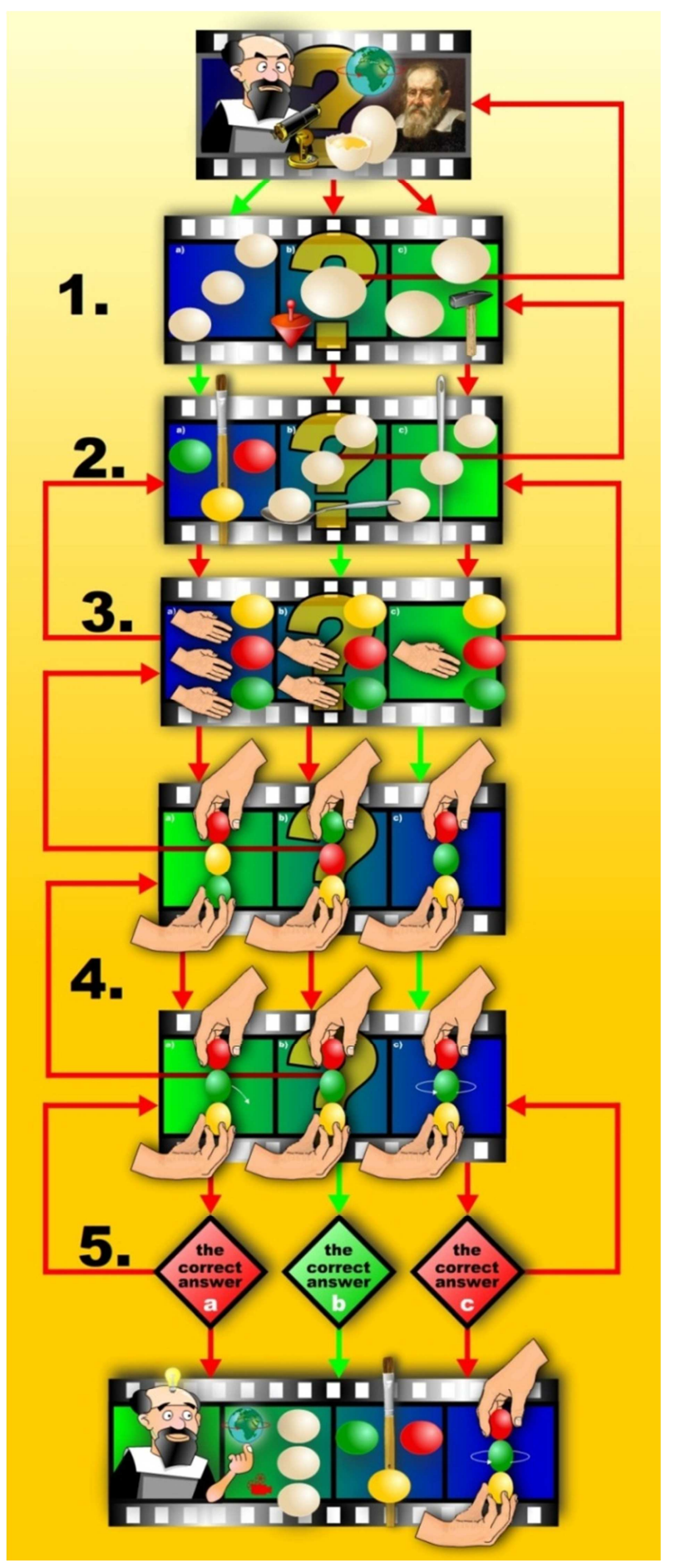

Modul chart 1. The algorithm scheme of solving the heuristic-programmed scientific task.

After solving this virtual task pupils should try to solve practically, manipulatively and experimentally the task which entice children to develop interest for science.

\section{Methods}

In this research we covered wider region comprising three different towns, Sombor (1 elementary school), Subotica (2 schools) and Kula ( 2 schools) in the Autonomous Province of
Vojvodina, in the Republic of Serbia(map 1).

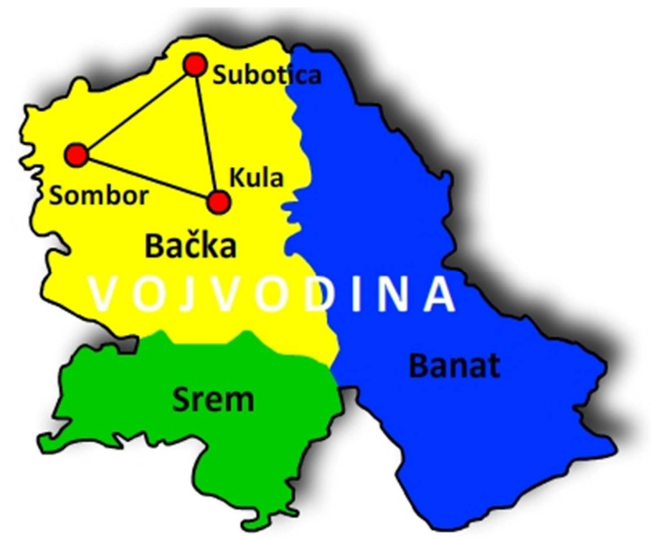

Map 1. Republic of Serbia - the Autonomous Province Vojvodina, Cities where the Research was conducted.

The methodology was based upon investigation and readings of scientific and specific literature, scientific papers including our own practical researches. During the research the e-animated class work content method was applied, poll and questionnaire as the instrument.

When analizing the results a descriptive and statistical method was applied presenting the data with charts.

During the solving the e-model of animated scientific task the following methods were used: flipped classroom and heuristic-programmed functional-logical method, the method of individual gathering of the information from the Internet, the method of work with didactic material and the experimental method.

\section{Analysis}

The research was done in two counties of the Autonomous Province of Vojvodina. Five elementary schools were included and the fourth grade pupils:

1. OŠ Nikola Vukićević in Somborwith 93 pupils,

2. OŠ Jovan Mikićwith 75 pupils and OŠ Miloš Crnjanskiwith 25 pupils from Suboticaand

3. OŠ Isa Bajić in Kulawith 62 pupils and OŠ Petefi Šandor with 69 pupils.

Therefore, the overall number of participants who filled the questionnaire is 324 pupils. The inquiry included all pupils at hand due to the pedagogic reasons so as not to make any of the children feel less worthy.

However, due to the problem of uneven classes regarding the number of pupils (that varies from 15 to 32), achievement (over $90 \%$ of pupils have excellent achievement in the previous grade that is a big and unreal figure and represents the problem in whole of Serbia) of the pupils we were not able to compare them on these grounds (excellent-very goodgood) and we were not able to do so because there was an uneven number of boys and girls. Took at random in all three centers we choose the number of 90 pupils per a center (45 girls and 45 boys whilst the achievement level we did not take in consideration). Of all the pupils by random selection 
270 pupils were involved in the process.

Chart 1, presents the results of the questionnaire which 90

pupils of OŠ Nikola Vukićević in Sombor have done.

Chart 1. the results of the pupils attending OŠ Nikola Vukićević in Sombor.

\begin{tabular}{|c|c|c|c|c|c|c|c|c|c|c|c|c|c|}
\hline \multirow[b]{3}{*}{ answers } & \multicolumn{13}{|c|}{ Collective presentation of the correct and the incorrect answers in theSTEPS(girls and boys- Sombor) } \\
\hline & \multicolumn{2}{|c|}{ STEP 1} & \multicolumn{2}{|c|}{ STEP 2} & \multicolumn{2}{|c|}{ STEP 3} & \multicolumn{2}{|c|}{ STEP 4} & \multicolumn{2}{|c|}{ STEP 5} & \multicolumn{2}{|c|}{$\sum$ answers } & \multirow{2}{*}{$\frac{\sum \text { answers }}{T+\perp}$} \\
\hline & $\mathrm{T}$ & $\perp$ & $\mathrm{T}$ & $\perp$ & $T$ & $\perp$ & $T$ & $\perp$ & $\mathrm{T}$ & $\perp$ & $\mathrm{T}$ & $\perp$ & \\
\hline Girls(45) & 39 & 6 & 17 & 28 & 24 & 21 & 11 & 34 & 31 & 14 & 122 & 103 & 225 \\
\hline Boys $(45)$ & 36 & 9 & 13 & 32 & 16 & 29 & 17 & 28 & 30 & 15 & 112 & 113 & 225 \\
\hline$\sum$ & 75 & 15 & 30 & 60 & 40 & 50 & 28 & 62 & 61 & 29 & 234 & 216 & 450 \\
\hline
\end{tabular}

In the analysis of the achieved results in chart 1 we may notice that the girls provided somewhat greater number of correct answers (122) in comparison to the boys (112). Furthermore, when we take a look at the total number of correct answers in relation to the STEPS we see that the girls and the boys gave almost identical number of correct answers on the STEP $1(39,36)$. For a difference to this at the STEP 4 girls provided the least number of the correct answers (11), whilst the boys had the least number of the correct answers at the STEP 2 (13). The following is also interesting, at the STEP 5 even though the pupils only had to read and tick the correct answer, the girls as well as the boys, chose wrong answers (girls - 14; and boys - 15).

Let us see some of the characteristic answers at the STEP 1:

Because the eggs must not break! (T)

a) If the egg survives the collision with the darning needle then it is fresh.

b) Because we may use a hammer to break the egg and then see its thickness.

STEP 2:

a) Because the eggs can be discerned.(T)

b) Using a tea spoon and measuring its weight we may determine whether the egg is fresh.

c) When we pierce the egg with a needle, we can smell it and determine the freshness.

STEP 3:

a) For there are three eggs we need three hands.

b) The task says that anyone alone can do the test. We all have only two hands. ( $T$ )

c) Because one hand is enough.

STEP 4 (middle step):

a) I think it is the right answer because it looks like a traffic light.

b) It seems as it is a traffic light. (But I am not sure).

c) It looks like a traffic light, and green color means go!(T)
Solution:

a) The egg will flip out.

b) Nothing will happen.

c) If the egg is fresh it will revolve around its axis. It is the name of the task.( $\mathrm{T}$ )

We have to stress out that a correct answer that was provided mostly was not followed by a correct or logical explanation. This may happened if the pupils have chosen the answers randomly! On the other hand, almost $50 \%$ of the pupils did not explain their choice in a written form. All of these can be interpreted in different ways (from not understanding it to the shame that they may not provide a valid answer). Thus, the results that we have must be considered conditionally.

When it comes to the total presentation of the pupils and their correct answers the results are in the chart 2. Only two pupils gave all 5 correct answers (a boy and a girl). Most of the pupils gave three correct answers (girls -14 ; boys $-15=$ 29). Three pupils did not manage to provide a single correct answer (one girl and two boys). We may notice that the boys and girls are almost equal in number of the correct answers given at the testing.

The results that are achieved are the consequence of the traditional and reproductive way of teaching where pupils are drilled to repeat teacher's sentences and not to think functionally and logically. How symptomatic this is we may see on the examples of PhD Ranko Rajović, that are purposed for the parents and teachers. These examples are the tasks for the pre-school and school children and for the high school children who also cannot solve them which makes us think that this is a generational problem because the way children today are educated the same way their parents, teachers even grandparents were educated(https://www.youtube.com/watch? $\mathrm{v}=$ gvEki1Mpaxw, https://www.youtube.com/watch?v=Q6GKR2MYZR4,https:/ /www.youtube.com/watch?v=-E7GWiEjj u4).

Chart 2. the results of the pupils attending OŠ Nikola Vukiceviciin Sombor.

\begin{tabular}{llllllll}
\hline \multicolumn{7}{l}{ Collective presentation of the pupils that gave correct answers(girls and boys - Sombor) } \\
\cline { 2 - 8 } & $\mathbf{5}$ correct answers & $\mathbf{4}$ correct answers & $\begin{array}{l}\mathbf{3} \text { correct } \\
\text { answers }\end{array}$ & $\begin{array}{l}\mathbf{2} \text { correct } \\
\text { answers }\end{array}$ & $\mathbf{1}$ correct answers & $\begin{array}{l}\text { 0 correct } \\
\text { answer }\end{array}$ & $\sum$ pupils \\
\hline girls & 1 & 11 & 14 & 13 & 5 & 1 & 45 \\
boys & 1 & 8 & 15 & 13 & 6 & 2 & 45 \\
$\sum$ & 2 & 19 & 29 & 26 & 11 & 3 & 90 \\
\hline
\end{tabular}


Considering the results at two another centers in Subotica and Kula they do not show any significant deviation comparing to the results in Sombor which proves the claim that pupils are unprepared and probably that schools in Serbia all share the same situation that is presented by this research all regarding to this kind of the approach or learning method. It is quite peculiar that most wrong answers were at the STEP 2 (Sombor 30, Subotica 19, Kula 27), that is STEP 4 (Sombor 28, Subotica 25, Kula 30).In the STEP 5 (despite the correct answer), we have a lot of pupils who chose the wrong answers (Subotica 32, Kula 28), which proves that they have not understood the task.

Chart 3. the results of the pupils attending OŠ Jovan Mikićin Subotica.

\begin{tabular}{|c|c|c|c|c|c|c|c|c|c|c|c|c|c|}
\hline \multirow[b]{3}{*}{ answers } & \multicolumn{13}{|c|}{ Collective presentation of the correct and the incorrect answers in the STEPS(girls and boys - Subotica) } \\
\hline & \multicolumn{2}{|c|}{ STEP 1} & \multicolumn{2}{|c|}{ STEP 2} & \multicolumn{2}{|c|}{ STEP 3} & \multicolumn{2}{|c|}{ STEP 4} & \multicolumn{2}{|c|}{ STEP 5} & \multicolumn{2}{|c|}{$\sum$ answer } & \multirow{2}{*}{$\begin{array}{l}\sum_{T+\perp} \text { answer } \\
T+1\end{array}$} \\
\hline & $\mathrm{T}$ & $\perp$ & $\mathrm{T}$ & $\perp$ & $\mathrm{T}$ & $\perp$ & $\mathrm{T}$ & $\perp$ & $\mathrm{T}$ & $\perp$ & $\mathrm{T}$ & $\perp$ & \\
\hline $\operatorname{girls(45)}$ & 27 & 18 & 10 & 35 & 19 & 26 & 9 & 36 & 29 & 16 & 94 & 131 & 225 \\
\hline boys(45) & 23 & 22 & 9 & 36 & 21 & 24 & 16 & 29 & 29 & 16 & 98 & 127 & 225 \\
\hline$\Sigma$ & 50 & 40 & 19 & 71 & 40 & 50 & 25 & 65 & 58 & 32 & 192 & 258 & 450 \\
\hline
\end{tabular}

Chart 4. the results of the pupils attending OŠ Jovan Mikić in Subotica.

\begin{tabular}{|c|c|c|c|c|c|c|c|}
\hline & \multicolumn{7}{|c|}{ Collective presentation of the pupils that gave correct answers(girls and boys - Subotica) } \\
\hline & $\begin{array}{l}5 \text { correct } \\
\text { answers }\end{array}$ & $\begin{array}{l}\text { 4correct } \\
\text { answers }\end{array}$ & $\begin{array}{l}\text { 3correct } \\
\text { answers }\end{array}$ & $\begin{array}{l}\text { 2correct } \\
\text { answers }\end{array}$ & 1 correct answer & Ocorrect answer & $\sum$ pupils \\
\hline girls & 1 & 4 & 12 & 13 & 11 & 4 & 45 \\
\hline boys & 1 & 5 & 12 & 14 & 6 & 7 & 45 \\
\hline$\sum$ & 2 & 9 & 24 & 27 & 17 & 11 & 90 \\
\hline
\end{tabular}

Chart 5. the results of the pupils attending OŠ Isa Bajić and OŠ Petefi Šandor in Kula.

\begin{tabular}{|c|c|c|c|c|c|c|c|c|c|c|c|c|c|}
\hline \multirow[b]{3}{*}{ answers } & \multicolumn{13}{|c|}{ Collective presentation of the correct and the incorrect answers in the STEPS(girls and boys - Kula) } \\
\hline & \multicolumn{2}{|c|}{ STEP 1} & \multicolumn{2}{|c|}{ STEP 2} & \multicolumn{2}{|c|}{ STEP 3} & \multicolumn{2}{|c|}{ STEP 4} & \multicolumn{2}{|c|}{ STEP 5} & \multicolumn{2}{|c|}{$\sum$ answers } & \multirow{2}{*}{$\begin{array}{l}\sum \text { answers } \\
T+\perp\end{array}$} \\
\hline & $\mathrm{T}$ & $\perp$ & $\mathrm{T}$ & $\perp$ & $\mathrm{T}$ & $\perp$ & $\mathrm{T}$ & $\perp$ & $\mathrm{T}$ & $\perp$ & $T$ & $\perp$ & \\
\hline $\operatorname{girls}(45)$ & 39 & 6 & 11 & 34 & 23 & 22 & 13 & 32 & 31 & 14 & 117 & 108 & 225 \\
\hline boys(45) & 34 & 11 & 16 & 29 & 21 & 24 & 17 & 28 & 30 & 15 & 118 & 107 & 225 \\
\hline$\sum$ & 73 & 17 & 27 & 63 & 44 & 46 & 30 & 60 & 61 & 29 & 235 & 215 & 450 \\
\hline
\end{tabular}

Chart 6. the results of the pupils attending OŠ Isa Bajić andOŠ Petefi Šandor in Kula.

\begin{tabular}{llllllll}
\hline & \multicolumn{7}{l}{ Collective presentation of the pupils that gave correct answers(girls and boys - Kula) } \\
\cline { 2 - 8 } & $\begin{array}{l}\text { 5 correct } \\
\text { answers }\end{array}$ & $\begin{array}{l}\text { 4correct } \\
\text { answers }\end{array}$ & $\begin{array}{l}\text { 3correct } \\
\text { answers }\end{array}$ & $\begin{array}{l}\text { 2correct } \\
\text { answers }\end{array}$ & $\begin{array}{l}\text { 1 correct } \\
\text { answer }\end{array}$ & $\begin{array}{l}\text { 0correct } \\
\text { answer }\end{array}$ & $\begin{array}{l}\sum \\
\text { pupils }\end{array}$ \\
\hline girls & 1 & 8 & 11 & 14 & 6 & 5 & 45 \\
boys & 2 & 5 & 13 & 15 & 7 & 3 & 45 \\
$\sum$ & 3 & 13 & 24 & 29 & 13 & 8 & 90 \\
\hline
\end{tabular}

\section{Results}

Chart 7. collective results-total of the whole population of pupils according to the STEPS.

\begin{tabular}{|c|c|c|c|c|c|c|c|c|c|c|c|c|c|}
\hline \multirow[b]{3}{*}{ answers } & \multicolumn{13}{|c|}{$\begin{array}{l}\text { Collective presentation of the correct and the incorrect answers in the STEPS } \\
\text { (boys and girls together-Sombor, Subotica andKula) }\end{array}$} \\
\hline & \multicolumn{2}{|c|}{ STEP 1} & \multicolumn{2}{|c|}{ STEP 2} & \multicolumn{2}{|c|}{ STEP 3} & \multicolumn{2}{|c|}{ STEP 4} & \multicolumn{2}{|c|}{ STEP 5} & \multicolumn{2}{|c|}{$\sum$ answers } & \multirow{2}{*}{$\frac{\sum \text { answers }}{T+\perp}$} \\
\hline & $\mathrm{T}$ & $\perp$ & T & $\perp$ & $\mathrm{T}$ & $\perp$ & $T$ & $\perp$ & $\mathrm{T}$ & $\perp$ & $\mathrm{T}$ & $\perp$ & \\
\hline $\operatorname{Kula}(90)$ & 73 & 17 & 27 & 63 & 44 & 46 & 30 & 60 & 61 & 29 & 235 & 215 & 450 \\
\hline Sombor(90) & 75 & 15 & 30 & 60 & 40 & 50 & 28 & 62 & 61 & 29 & 234 & 216 & 450 \\
\hline Subotica(90) & 50 & 40 & 19 & 71 & 40 & 50 & 25 & 65 & 58 & 32 & 192 & 258 & 50 \\
\hline$\sum$ & 198 & 72 & 76 & 194 & 124 & 146 & 83 & 187 & 180 & 90 & 661 & 689 & 1350 \\
\hline
\end{tabular}

In the chart 7 total result of the research is presented and categorized according to the towns where the schools are settled and by the STEPS. In general we may say that this task has been done almost half and it may be assessed by the grade 3 because the relation between Tand $\perp$ answersare 661 to 689 .

Using school terminology the grades would be:
$1=0-270 ; 2=271-540 ; 3=541-810 ; 4=811-1080 ;$ $5=1081-1350$ correct answers.

If we take a look of each school individually the situation is pretty similar: Kula (235) and Sombor (234) would get an average grade $3+$, and Subotica (192) grade 3.

List of points:

$1=0-90 ; 2=91-180 ; 3=181-270 ; 4=271-360 ; 5=$ 
$361-450$ correct answers.

Therefore, the best ranked is (235), then Sombor (234) and Subotica with 192 correct answers.

The most of the correct answers were provided in the STEP 1 (198), the least in STEP 2 (76), whilst in the STEP 5, where it was not to expect, there were 90 wrong answers.

However, theclearest insight in the achievement rate considering the solving the tasks we see in the chart 8 . The total of the results considering solving of the whole e-task are not only bad but as expected they present a real situational result, as well.

Amongst everyone who participated in the research questionnaire (270): 5 correct answers were given only by 7 pupils or 2,59\%(3 girls and 4 boys). Three of them are from Kula. The biggest number of pupils $(82,30,37 \%)$ gave two correct answers; then $(77,28,51 \%)$ those with three correct answers; while the same number of pupils $(41,15,18 \%)$ gave four and one correct answer. No correct answers were given by 22 pupils. or $8,14 \%$.

Chart 8. The total of the results of all the pupils participating at the research.

\begin{tabular}{|c|c|c|c|c|c|c|c|}
\hline \multicolumn{8}{|c|}{ The total nuber of pupils who participated at the questionnaireand their results considering the success in solving the e-task } \\
\hline ANSWERS & $\begin{array}{l}5 \text { correct } \\
\text { answers }\end{array}$ & $\begin{array}{l}\text { 4correct } \\
\text { answers }\end{array}$ & $\begin{array}{l}\text { 3correct } \\
\text { answers }\end{array}$ & $\begin{array}{l}2 \text { correct } \\
\text { answers }\end{array}$ & $\begin{array}{l}1 \text { correct } \\
\text { answer }\end{array}$ & $\begin{array}{l}\text { 0correct } \\
\text { answer }\end{array}$ & $\sum$ pupils \\
\hline Kula & 3 & 13 & 24 & 29 & 13 & 8 & 90 \\
\hline Sombor & 2 & 19 & 29 & 26 & 11 & 3 & 90 \\
\hline Subotica & 2 & 9 & 24 & 27 & 17 & 11 & 90 \\
\hline$\sum$ pupils & 7 & 41 & 77 & 82 & 41 & 22 & 270 \\
\hline
\end{tabular}

In the chart 9, the towns are ranked by the level of the success and the average grade for each town is presented. "The most successful" was the elementary school in Sombor with the average grade 2,62, followed by Kula with 2,33 and Subotica with 2,10 . The average grade for all three towns is 2,35 .

Chart 9. the achieved average grade in the research in total and in the towns.

\begin{tabular}{|c|c|c|c|c|c|c|c|c|c|}
\hline \multicolumn{10}{|c|}{ The total number of grades and the average achieved grade of the pupils regarding the success in solving the e-task } \\
\hline QUESTIONS & $\begin{array}{l}5 \text { correct } \\
\text { answers }\end{array}$ & $\begin{array}{l}4 \text { correct } \\
\text { answers }\end{array}$ & $\begin{array}{l}3 \text { correct } \\
\text { answers }\end{array}$ & $\begin{array}{l}2 \text { correct } \\
\text { answers }\end{array}$ & $\begin{array}{l}1 \text { correct } \\
\text { answer }\end{array}$ & $\begin{array}{l}0 \text { correct } \\
\text { answers }\end{array}$ & $\begin{array}{l}\sum_{\text {GRADE }} \\
\text { GR }\end{array}$ & $\begin{array}{l}\sum_{\text {pupils }} \\
\text { pula }\end{array}$ & $\begin{array}{l}\text { Average } \\
\text { grade }\end{array}$ \\
\hline Sombor & 10 & 76 & 87 & 52 & 11 & 3 & 236 & 90 & 2,62 \\
\hline Kula & 15 & 52 & 72 & 58 & 13 & 8 & 210 & 90 & 2,33 \\
\hline Subotica & 10 & 36 & 72 & 54 & 17 & 11 & 189 & 90 & 2,10 \\
\hline$\sum$ & 35 & 164 & 231 & 164 & 51 & 22 & 635 & 270 & 2,35 \\
\hline
\end{tabular}

The achieved results reflect inability of the pupils to provide more qualitative answers on the kind of demands or tasks they meet. Our intention is to indicate that there is no time wait and there are good ideas to improve the situation in the schools in the Republic of Serbia.

The most popular proverb in sport from 1908 was - it's not important to win, it's important to participate, that is faulty attributed to the founder of the modern Olympic games Pierre de Coubertin(1863-1937), (http://www.politika.rs/rubrike/sport-aktuelno/Olimpijskeigre-London-2012/Mesto-na-kojem-se-rodilo-nije-vaznopobediti-vazno-je-ucestvovati.lt.html)must not be the only motif of Serbia when its pupils take the upcoming PISA tests. In contrary, the tendency we ought to establish by the next testing should be constant and substantial improvement and advance measured by the results. It can only happen if some serious systemic changes take place considering the revision and programming of our national educational system.

\section{Conclusion: Albeit, It does move!}

Older generations remember with admiration when some of their peers by hart recited some lyrics of the famous poets or passages from some novels. Today we can se this very rarely, maybe when visiting a theatre... the times and the children have been changing and school must follow these changes...The progress is unstoppable (although there are pros and cons, as well) but society has to go hand in hand with the changes because new generations oblige us to do so... Of course, not every human abilities known before should not be forgotten, rather we should stimulate all abilities equally and hold the right measure. Any exclusivity is counterproductive.

The e-learning model presented involving animated content, flipped classroom and heuristic-programmed and branched model of the learning approach that stimulates functional and logical thinking should me quite motivational and should enable individual progress of pupils. That this is true we saw throughout direct contact and work with the pupils participating in the research. The common question they asked was: Are you going to come tomorrow also?

Furthermore, the model is apt for acquiring, revision and evaluation of the knowledge from all school subjects. Our presentation suggested group form of work but it may be done individually, as well. The presented e-model is suitable for creating a sequence of movies that would obtain a single 
or several topics. This learning and school work should be combined with practical-manipulative, experimental and other forms and methods of works that is conditioned by available material and technical resources... whilst, on the other hand, it saves money, material, space, time...

Serbia has inner potential to change this "tired" educational system. However, there is little will for accepting the changes offered by the people from Serbia. For example, the aforementioned project NTC has persisted in many countries but not in Serbia. Additinoanlly, the inspiration and the potential to change the existing educational system we may not seek only from the best but form the intellectual and professional potential of the state and rich heritage of our nation (its proverbs, fairy tales, riddles, sayings, aphorisms and etc.)

As having some future perspective of such approaches it would be great to create a resource base of such models and similar researches and undertake a comparison between pupils form Serbia and pupils of the countries that are leading on the list of the most advanced educational systems of the world.

\section{References}

[1] Grunwald Associates LLC. (2013)Living and Learning with Mobile Devices: What Parents Think About Mobile Devices for Early Childhood and K-12 Learning, http://www.corp.att.com/edu/docs/mobile_kids.pdf

[2] Hilčenko, S. (2014a) Model of Animated-Scientific Project in $4^{\text {th }}$ grade, Media, Culture and Public Relations, Croatian Communication Association, Vol.5 No. 2,pp. 241244,http://hrcak.srce.hr/index.php?show=clanak\&id_clanak_j ezik $=188976$

[3] Hilčenko, S. (2014b)Upside down learning approaches for Generation "Z", VII Internacional Interdisciplinary Scientific Professional Conference" New Horizons in Education, Culture and Sports", College of Vocational Studies, Subotica, Vocational Training for Preschool Teachers and Sports Trainers, e-Collected papers, pp. 26-30.

[4] Hilčenko, S. (2013a)How to "Catch" Ice Cube? HeuristicProgrammed Animated Model of Scientific e-task in $4^{\text {th }}$ grade, Studia Scientifica, 2/2013, Facultatis Paedagogicae, Univeritas Catholica, Ružomberok,Slovakia,ročnik XII., pp. 144-151.

[5] Hilčenko, S. (2013b) A Model Of Programmed-Heuristic Animated Movie With Direct Manipulation Of The Content Intended For Learning On An Example Of A Logical Task In Elementary School Class Work, SirIKT 2013, Interlacing Education and Research with ICT, Slovenia, Kranjska Gora,Collected papers, pp. 774781,https://www.academia.edu/4393470/A

[6] Hilčenko, S. (2012a)Watching Cartoons, and yet learning Maths!, Media, Culture and Public Relations, Croatian Communication Association, Vol.3 No.1, pp. 5357,http://hrcak.srce.hr/index.php?show=clanak\&idclanakjezik $=118199$
[7] Hilčenko, S. (2012b) Maths + Multimedia = "Bypass" from manipulation to abstraction!, Themes - Journal for Social Research, Niš, number 1, pp. 305317,http://teme.junis.ni.ac.rs/teme1-2012/teme\%201-201218.pdf

[8] Hilčenko, S. (2011) DVD - Educational Multimedia and Interactive Animated Film with Quiz: "'Point, line ...",with Didactic-Methodological Manual, intended for Children of Preschool and lower School Age for the Elementary forming of mathematical notions (geometric figures), Preschool Teacher and Sport Trainer High school - Subotica, University of Novi Sad, Republic of Serbia

[9] Mayer, E. R. (2005) The Cambridge Handbook of Multimedia Learning, New York: Cambridge University Press, http://hrcak.srce.hr/index.php?show=clanak\&idclanakjezik=1 18199

[10] Piaget, J., Inhelder, B. (1978)The intellectual development of the child, Department of textbooks and teaching aids, Belgrad.

[11] Rajović, R. (2009) Nikola Tesla Center (NTC) IQ Child - Care of Parents, Authors Edition, Novi Sad

[12] Rakočević, B. (2014)South Korea has taken the lead from Finland, Chronicle, The Educational Review,No. 2623 (22), year LXX.

[13] WebsitePolitics, http://www.politika.rs/rubrike/Drustvo/t49789.1t.html

[14] WebsiteYou Tube https://www.youtube.com/watch?v=Q6GKR2MYZR4

(RS),

[15] Website IKL,http://www.ixl.com/math/

[16] Website Brain POP,http://www.brainpop.com/

[17] Website Lilibi.si,http://www.lilibi.si/

[18] Website Hamster, Portal of Scientific Journals ofCroatia,http://hrcak.srce.hr/index.php?show=clanak\&id_cla nak_jezik=118199

[19] Website Themes Journal for Social Research, http://teme.junis.ni.ac.rs/teme1-2012/teme\%201-2012-18.pdf

[20] Ph.D. Black,B. John, Teachers College, Columbia University ( $2^{\text {nd }}$ International Conference on e-learning ICEL 2007, Website Edupoint (Journal papers), $\mathrm{http} / / /$ edupoint.carnet.hr/casopis/57/clanci/1.html

[21] Website The World of Computers, http://www.sk.rs/2013/02/skin03.html

[22] Website S media, http://www.smedia.rs/ona/vest/8142/a.html?id=8142

[23] Website Childhealthy Eating,http://www.ishrana.net/MESORIBA-JAJA-Jaja-324

[24] Website Mouthful,http://www.zalogaj.com/pages/view-224korisni-saveti-drugi-deo

[25] WebsiteYumama,http://www.yumama.com/dete/ishranadece/1565-jaje-je-zdrav-izbor.html

[26] Website Agriculture http://poljoprivreda.info/?oid=6\&id=234

info,

[27] Website Domestic.de http://www.domaci.de/viewtopic.php?t=939
Portal, 
[28] Website Valentin Kuleto Professional Blog, http://www.valentinkuleto.com/2012/05/3-metode-ucenja-zanove-generacije

[29] Website Wikipedia,http://sr.wikipedia.org/wiki/

[30] Website Having Our Hands in Tests, http://rukautestu.vin.bg.ac.rs/?Page_Id=50

[31] Website IOSR Journals, http://www.iosrjournals.org/iosrjrme/papers/Vol-1\%20Issue-3/G0134449.pdf

[32] Website You Tube (Republic of Serbia), https://www.youtube.com/watch?v=gvEki1 Mpaxw, https://www.youtube.com/ watch?v=Q6GKR2MYZR4,https://www.youtube.com/watch? $\mathrm{v}=-\mathrm{E} 7 \mathrm{GWiEjju} 4$
[33] Website Politics Online, http://www.politika.rs/rubrike/sportaktuelno/Olimpijske-igre-London-2012/Mesto-na-kojem-serodilo-nije-vazno-pobediti-vazno-je-ucestvovati.lt.html

\section{Biography}

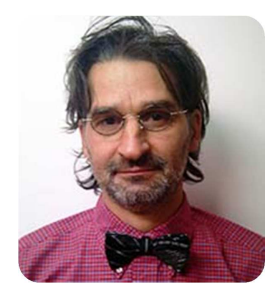

Slavoljub Hilčenko (PhD. University of Novi Sad, Serbia) associate professor at the Vocational College for Education of Preschool Teachers and Sport Trainers in Subotica. He teaches at the subjects of Informatics, Elementary forming of mathematical notions, Educational technology, Animations, Graphical design. He lives in Sombor. 